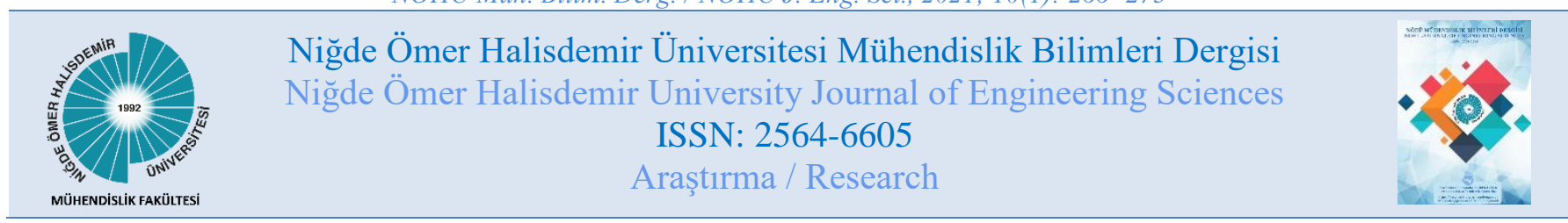

\title{
Harçsız yığma duvarlı betonarme çerçevenin nümerik analizi
}

\section{Numerical analysis of reinforced concrete frame with drry stack masonry infill}

\author{
Hakan Koman 1,* (D), Halil Nohutcu 1 (iD)

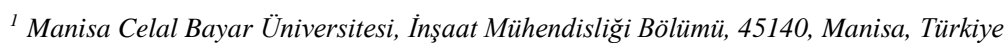

\section{Özet}

Bu çalışmada betonarme çerçeveye harçsız tuğlalı duvar etkisi nümerik analiz yoluyla araştırıldı. Harçsız tuğlalı duvarlar, geleneksel duvarlar kadar çerçeveyi rijitleştirmeden adeta bir sürtünmeli sönümleyici gibi görev yaparak, çerçevenin enerji tüketme kapasitesini arttırmaktadır ve bu konuda mevcut çalışmalar vardır. Bu çalışmada ayrıca duvarın çerçeveye bağlantısının rijit veya esnek olmasının çerçeve davranışına etkisi araştırılmıştır. Rijit birleşim için harç, esnek birleşim için ise poliüretan tabanlı yapıştırıcı kullanılmıştır. ABAQUS programı ile çerçevelere yapulan $20 \mathrm{~mm}(\% 2.5$ yanal öteleme orant) itme analizlerinde esnek birleşim kullanılmasının kilitli duvarlı çerçevenin taşıdı̆̆ yükü arttırdığl, duvar ile çerçeve arasındaki bölgede gerilme yı ğlmaların azaltarak duvarın daha az hasar almasını sağladığı görülmüștür. Duvarsız çerçeveye nazaran, harçsız tuğlalı çerçevenin enerji tüketim kapasitesi daha fazla olmuştur.

Anahtar kelimeler: ABAQUS, Harçsız yığma, Polymer Pm, Poliüretan yapıştırıcı, Esnek birleşim.

\section{Giriş}

Geçmişte, Kocaeli 1999, Northridge 1994, Erzincan 1992, Landers 1992, Kobe 1995 gibi birçok yıkıcı deprem meydana gelmiştir. Birçok can kaybı ve ekonomik hasar birçok binanın yıkılması sonucu meydana gelmiştir. Güçlü yer hareketlerinin yıkıcı etkilerini alt edebilmek için yapıların enerji tüketim kapasitelerini arttırmak bir zorunluluktur. $\mathrm{Bu}$ amaçla sismik sönümleyiciler kullanılmakta ve özellikleri geliştirilmektedir. Sürtünmeli, metalik akmaya dayalı, viskoz ve viskoelastik sönümleyiciler önceki çalışmalarda kullanılan pasif enerji sönümleyicilerden bazılarıdır. Halihazırda anlaşılmıştır ki, bu tarz sismik sönümleme cihazları, yapının rijitliğini arttıran betonarme perde eklenmesi gibi geleneksel güçlendirme metotlarıyla kıyaslandığında ekonomik ve alternatif bir güçlendirme çözümüdür. İstanbul'da yapılan bir güçlendirme çalışmasında görülmüştür ki sürtünmeli sönümleme cihazları, bu cihazlar yerleştirilirken bina sakinlerini rahatsız etmediğinden ve taşınmaya zorlamadığından geleneksel güçlendirme metotlarıyla kıyaslandığında daha iyi bir alternatiftir [1]. Sismik bölgelerde çerçeve içindeki dolgu duvarlar korunma ve alanı bölme amaçlı kullanılmaktadır ve geçmişteki tasarımlarda bu dolgu duvarların yapı deprem davranışına etkisi ihmal edilmiştir. Fakat gerçekte dolgu duvarlar güçlü depremler esnasında yapının rijitlik, periyot, süneklik gibi özelliklerini duvar ile çerçeve arası etkileşimden dolayı değiştirmektedir. Birçok araştırmacı bu problemi araştırmış ve hayali basınç çubuğu kullanarak duvar davranışının modellenmesini

\begin{abstract}
In this study the effect of a wall with dry stack masonry to a RC frame was investigated through numerical analysis. Dry stacked walls increases the energy dissipation of frames by acting as frictional energy dissipation devices, without increasing the stiffness of frame like a traditional wall and many studies exist about this. In this study, also, the effect of the joint between wall and frame was investigated by using flexible and stiff joint. For stiff joint mortar was used, and for flexible joint, a polyurethane based adhesive was used. In the ABAQUS analysis in which the RC frames were pushed $20 \mathrm{~mm}$ (\%2.5 drift ratio), it was concluded that using flexible joint increases the load carried by frame, and decreased the damage in the wall by decreasing the stress concentrations in the region between wall and frame. When compared with the RC frame without walls, the energy dissipation of dry stacked masonry infilled frame is higher.
\end{abstract}

Keywords: ABAQUS, Dry stack masonry, Polymer pm, Polyurethane adhesive, Flexible joint

önermişlerdir. Bu yaklaşım ayrıca Eurocode 8, FEMA 356 gibi bazı deprem yönetmelikleri tarafından da benimsenmiştir [2]. Diğer taraftan, mimari sebeplerle zaten yapılan dolgu duvarları enerji sönümleyiciye çevirmek mantıklı bir fikirdir. Lin vd. [3] tarafindan yapılan bir deneysel çalışmada görülmüştür ki, harçsız yığma dolgu duvar, çerçeve elastik aşamadayken, çerçevenin rijitliğini arttırmadan, çerçevenin enerji tüketimini arttırmaktadır. Bu sebeple Totoev [4] diğer çalışmasında harçsız yığma dolgu duvarı bir enerji sönümleme cihazı olarak modellemeyi ve Jacobsen yaklaşımını kullanarak çerçevenin dinamik analizi için yeni bir sönüm oranı hesaplamayı önermiştir. Jacobsen yaklaşımında cihaz tarafından tüketilen enerjiyi çerçevenin elastik şekil değiştirme enerjisine oranlayarak yapısal davranışın doğrusal olmayan aşaması için yeni bir sönüm oranı hesaplanmaktadır. Totoev ayrıca dolgu duvar çerçeve arası birleşim özelliklerinin (boşluk olması-olmaması), çerçevenin enerji tüketim özelliklerini değiştirdiğini söylemiştir. Diğer çalışmasında değişik boşluk doldurucu malzemeler denemiş ve etkilerini araştırmıştır [5].

Diğer bir çalışmada detaylı bir sonlu eleman analizi DIANA programiyla yapıldıktan sonra Seismostruct programının elastik olmayan duvar özelliği kullanılarak basitleştirilmiş bir nümerik analiz de yapılmıştır ve görülmüştür ki, yarı kilitli harçsız duvar yapının sünekliğini kayda değer şekilde azaltmadan yapının enerji tüketimini arttırmada avantajlıdır [6].

Geçmiş bir çalışmada ayrıca gösterilmiştir ki, betonarme kolonlar eksenel yüklerden dolayı taşıma gücünü

\footnotetext{
* Sorumlu yazar / Corresponding author, e-posta / e-mail:hakankoman@hotmail.com (H. Koman)

Geliş / Recieved: 25.08.2020 Kabul / Accepted: 18.11.2020 Yayımlanma/Published: 15.01.2021

doi: $10.28948 /$ ngmuh.785286
} 
yitirdiğinde, harçsız duvar çerçevelere eksenel yükleri taşımada yardım etmekte ve bloklar arasındaki sürtünmeden dolayı enerji tüketmeye çerçeve elastik olmayan aşamadayken de devam etmektedir. Harçsız duvar dolgulu çerçeveler duvarsız çerçeveye nazaran daha fazla yatay yük taşıma kapasitesine sahiptirler. Yazarlar ayrıca harçsız da olsa duvarın yatay yüklemede bir basınç çubuğu gibi davrandığından bahsetmişlerdir [7].

Türkiye'de yerel yarı kilitli delikli tuğlalarla bir çalışma yürütülmüş fakat çerçeve yanal yük kapasitesinin, dolgu duvarsız çerçevelerle kıyaslandığında, artmadığı görülmüştür. [8]. Bu çalışmanın yazarlarına göre boşluklu tuğla kullanmak, harçsız yığma dolgu duvar bir hayali basınç çubuğu davranışı gösterdiğinde zayıf bir direnç oluşmasına sebep olmuştur ve bu olgu çerçevenin yatay yük kapasitesinin artmasına yardımcı olmamıştır.

Diğer taraftan, Krakow Teknoloji Üniversitesi'nde Kwiecien [9] tarafından esnek birleşim metodu önerilmiş ve gösterilmiştir ki, bir hayli deforme olabilen yapıştırıcılar kullanılarak birleşimlerdeki gerilme yığılmalarını azaltmak ve birleşimlerin yük taşıma kapasitelerini arttırmak mümkündür. Kwiecien [9] tarafından yapılan deneylerde esnek yapıştırıcıyla onarılmış tuğlaların hiç deforme olmamış sağlam eşlerine nazaran eğilme deneyinde daha fazla yük taşıdığı görülmüştür(hem de yapıştırıcının çekme dayanımı tuğlalardan düşük olmasına rağmen). Kwiecien, [9-12] esnek birleşimlerin yapıların enerji tüketim kapasitelerini arttırdığını gösteren birçok çalışma yapmıştır ve bazılarında esnek malzemenin nasil modellenebileceğinden ve malzemenin mekanik özelliklerinden bahsetmiştir.

$\mathrm{Bu}$ çalışma, harçsız yığma duvarı bir enerji tüketme sistemi olarak incelemiştir ve bununla beraber çerçeve ile duvar arasında esnek birleşim kullanılmasının etkisini Abaqus ile yapılan bir sonlu eleman analiziyle incelemiştir. Abaqus önceki bir çalışmada da belirtildiği üzere deney sonuçlarına yakın sonuçlar elde edilmek istendiğinde kullanılabilecek güçlü bir araçtır [13]. Bu çalışma sonucunda harçsız duvarın enerji tüketimini arttırarak ve geleneksel duvarlar kadar rijitliği arttırmadığı için yapının periyodunu büyüterek, yapıların depreme karşı davranışını iyileştirmesi ve esnek birleşim kullanılarak yapı-duvar etkileşimi dolayısıyla duvarların ve yapının aldığı hasarın azaltılması hedeflenmiştir.

\section{Materyal ve metot}

\section{1 Çerçeve tasarımı}

40x40 cm ebatları olan kolon ve kirişlerden oluşan bir çerçeve, Türk Deprem yönetmeliğine (2007) göre dizayn edilmiştir. ( $\mathrm{Bu}$ yönetmeliğin kullanılma sebebi tasarlanan çerçevenin yerel bir prefabrik firmasında 2018 Türkiye Bina Deprem Yönetmeliği yürürlüğe girmeden önce inşa ettirilmesidir ve ileride yapılması planlanan deneysel çalışmalardır.) Çerçeve $4 \mathrm{~m}$ genişliğinde, $3 \mathrm{~m}$ yüksekliğindedir. Tasarım yapılırken her bir kolon için $600 \mathrm{kN}$ düşey yük ve çerçeve için $250 \mathrm{kN}$ yatay yükleme dikkate alınmıştır. Yapısal analiz sonucunda betonarme dizayn için şu kuvvetler bulunmuştur: Kolon için: $\mathrm{N}_{\mathrm{d}}=700.62 \mathrm{kN}$ (eksenel kuvvet), $\mathrm{V}_{\mathrm{d}}=126.44 \mathrm{kN}$ (kesme kuvveti), $\mathrm{M}_{\mathrm{d}}=206631.06 \mathrm{kNmm}$ (moment) ve kiriş için $\mathrm{V}_{\mathrm{d}}=$ $92.5 \mathrm{kN}, \mathrm{M}_{\mathrm{d}}=172710.92 \mathrm{kNmm}$. Çerçeve $1 / 4$ oranında küçültülmüştür ve $12 \times 12 \mathrm{~cm}$ ebatlı (konstrüktif nedenlerle ve yapılması planlanan deney için kullanılacak tuğlanın üretici firmasının ebatları dolayısıyla ), $0.75 \mathrm{~m}$ yüksekliğinde, $1 \mathrm{~m}$ genişliğinde bir çerçeve belirlenmiştir. (Betonarme dizayn yeni ebatlar için kontrol edilmiştir ve dizaynın değişmediği görülmüştür.) $\mathrm{Bu}$ süreçte geçmiş çalışmalarda bahsedilen modelleme yasaları kullanılmıştır [14, 15]. Çerçevenin küçültülmesinde pratik gerçek model yaklaşımı kullanılmıştır. Çerçevenin detayları Şekil 1'de görülmektedir, Şekil 1'de görülmeyen etriye sıklaştırılması Türk deprem yönetmeliği hükümleri uyarınca $12 \times 12 \mathrm{~cm}$ ebatlı çerçevenin kolon-kiriş birleşim bölgesine uygulanmıştır.

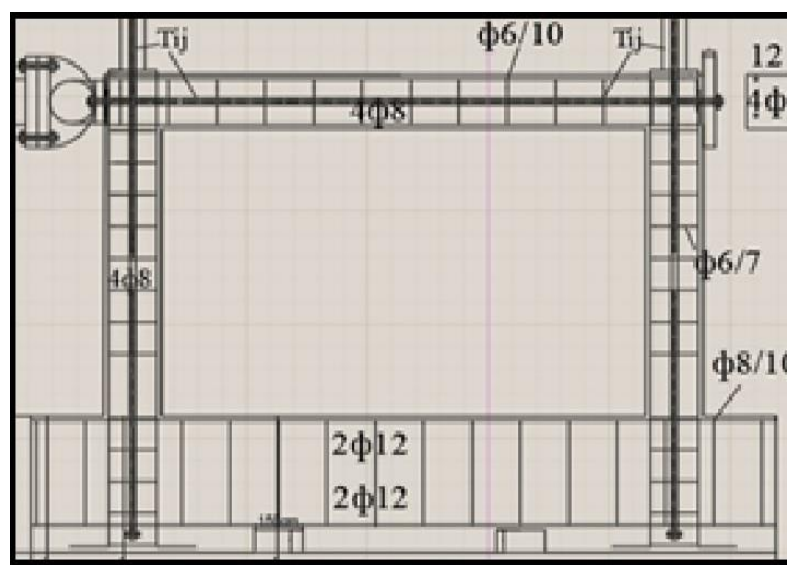

Şekil 1. Ölçekli çerçeve donatı detayları

\subsection{Abaqus modellemesi}

\subsubsection{Betonun modellenmesi}

Betonun davranışını modellemek için Abaqus'te yer alan CDP (Concrete Damaged Plasticity) modeli kullanılmıştır. CDP modeli, Lubliner vd. tarafından öne sürülen akma yüzeyini kullanır ve J. Lee ve G, Fenves tarafından önerilen çekme ve basınçtaki dayanımın farklı evrimini içeren modifikasyonları da içerir [13]. CDP modeli Drucker-Prager modelinin modifiye edilmiş halidir. $\mathrm{K}_{\mathrm{c}}$ parametresi 1 'e eşit olduğunda model Drucker-Prager modeli olmaktadır. Şekil 2'de [13] bu durum gözükmektedir. Von Misses kırılma hipotezinde hacim değiştiren hidrostatik basınç dikkate alınmamaktadır. Fakat Drucker Prager teorisinde bir akma kriteri saptamak için hidrostatik basınç ta deformasyona yol açan diğer gerilmelerle birlikte dikkate alınmaktadır.

Beton için olan gerilme-şekil değiştirme ilişkileri Şekil 3 'teki [13] gibi düşünülmüştür ve $\mathrm{d}_{\mathrm{c}}$ ile $\mathrm{d}_{\mathrm{t}}$ parametreleri - ki bunlar betonun elastisitesini basınçta ve çekmede bozan etkileri gösterir- sıfır kabul edilmiştir. Maksimum gerilmeye karşılık gelen birim şekil değişimi C25 için 0.002 alınmış, ve elastisite modülü de $31000 \mathrm{MPa}$ alınmıştır.

Şekil 4'te [17] görüldüğü üzere p-q düzleminde ölçülen genişleme açısına dilatasyon açısı denir ve beton için 38 derece alınmıştır. Bu değer önceki bir çalışmada deney sonuçlarıyla uyumlu bir sonuç verdiği için kabul edilmiştir [16]. 


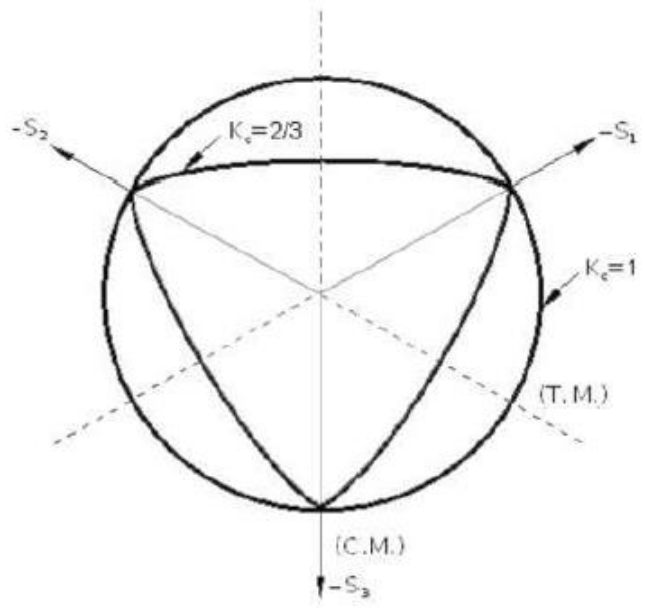

Şekil 2. CDP modeli

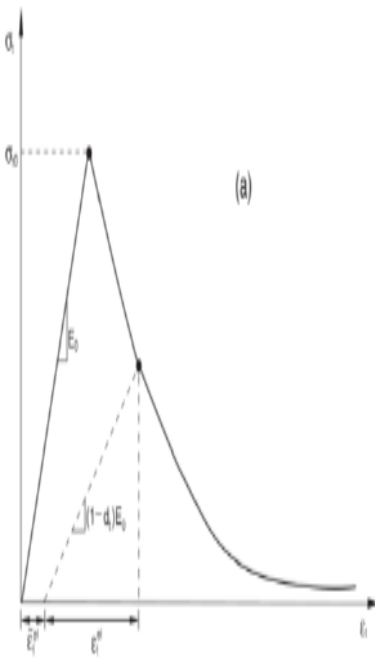

(a) çekme

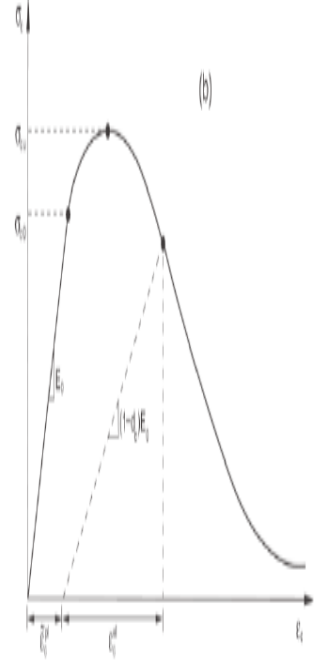

(b) basinç
Şekil. 3. Betonun gerilme şekil değiştirme ilişkileri

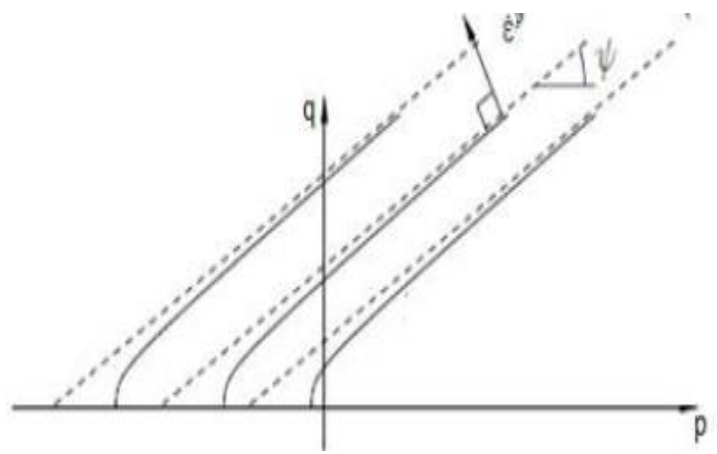

Şekil 4. Dilatasyon açısı

$\mathrm{f}_{\mathrm{b} 0} / \mathrm{f}_{\mathrm{c} 0}$ oranı 1.16 alınmıştır. $\mathrm{f}_{\mathrm{b} 0}$ : betonun iki eksenli gerilme halindeki dayanımı, $\mathrm{f}_{\mathrm{c} 0}$ : betonun tek eksenli gerilme halindeki dayanımıdır. Betonun çekme dayanımının basınç dayanımına oranını ifade eden eksantrisite değeri 0.1 kabul edilmiştir.

\subsection{2 Çelik modellemesi}

Nümerik analiz sonuçlarını doğrulamak için bir deneysel çalışma yapılması planlanmaktadır, bu yüzden üreticilerden çelik çekme deneyi sonuçları alınarak modelleme için kullanılmıştır. S420B için (bunlar 8mm çaplı donatılarda kullanılmıştır) akma dayanımı $491 \mathrm{MPa}$, çekme dayanımı $553 \mathrm{MPa}$ alınmıştır. S420 için (bunlar $12 \mathrm{~mm}$ çaplı donatılarda kullanılmışır) akma dayanımı $490 \mathrm{MPa}$, çekme dayanımı $610 \mathrm{MPa}$ alınmıştır. SAE5.5 çelikleri etriye olarak kullanılmıştır ve akma dayanımı $277 \mathrm{MPa}$, çekme dayanımı $387 \mathrm{MPa}$ alınmıştır. Etriyelerde SAE 5.5 çeliğinin kullanılma sebebi, nümerik analiz sonuçlarını doğrulamak için çerçevenin inşa ettirildiği fabrikada $6 \mathrm{~mm}$ çaplı S420S420B çeliğinin bulunmaması ve piyasada bulunamaması ve SAE 5.5 çeliğinin bulunabilmesidir.

\subsubsection{Tuğlaların modellenmesi}

Normalde bu tip bir çalışmada yarı-kilitli tuğlalar kullanılarak duvarın düzlemdışı davranışına katkıda bulunulması gerekmektedir. Daha önceki bir çalışmada yarıkilitli tuğlaların düzlem dışı devrilmeyi engellediği söylenmiştir [7]. Fakat gerçek durumu simule etmek amacıyla yerel bir fabrikada üretilen pres tuğlalar harçsız yığmayı modellemede kullanılmıştır ve duvarın düzlem dışı davranışı bu çalışmada incelenmemiştir. Şekil 5 'te tuğlanın gerçek resmi ve Abaqus modellemesi görülmektedir. Yarı kilitli tuğla yerine bu tuğlanın kullanılma sebebi ticari sebeplerle yerelde üretilen kilitli tuğlaların üretiminin durmuş olmasıdır ve nümerik analizi doğrulamak için ileride bir deney yapılmasının planlanmasıdır.

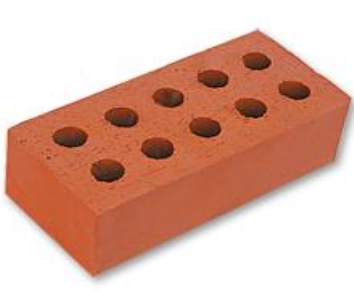

(a)

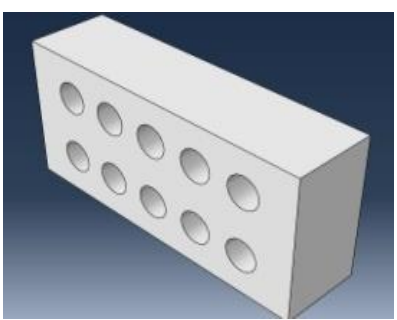

(b)
Şekil 5. (a) pres tuğla (b) abaqus modellemesi

Tuğlayı modellemek için yine CDP modeli kullanılmıştır fakat $K_{c}$ parametresi 1 alınarak Drucker-Prager modeline dönüştürülmüştür. Gerilme-birim şekil değiştirme değerleri daha önce yapılan bir çalışmada açıklanan parabolik ilişki kullanılarak elde edilmiştir.[18]. Bu ilişkide basınç durumunda akma şekil değiştirmesi taşınan maksimum gerilmenin 1/3'üne karşıllı gelen şekil değiştirme olarak alınmıştır. Ve parabolik bir ilişki varsayılmıştır. Bu ilişkiye ait grafik Şekil 6'da [18] görülmektedir. $G_{c}, f_{c}, \propto_{c}, h$ sırasıyla, basınç kırılma enerjisi, basınç gerilmesi, basınç şekil değiş̧irmesi, yüksekliktir. Model için, Denklem (1), (2) ve (3)' te görülen şu ilişkiler varsayılmıştır: 


$$
\begin{gathered}
\propto_{\mathrm{c} / 3}=-\frac{1}{3} \frac{\mathrm{f}_{\mathrm{c}}}{\mathrm{E}} \\
\propto_{\mathrm{c}}=-\frac{5}{3} \frac{\mathrm{f}_{\mathrm{c}}}{\mathrm{E}} \\
\propto_{\mathrm{u}}=\propto_{\mathrm{c}}-\frac{3}{2} \frac{\mathrm{G}_{\mathrm{c}}}{\mathrm{hf}_{\mathrm{c}}}
\end{gathered}
$$

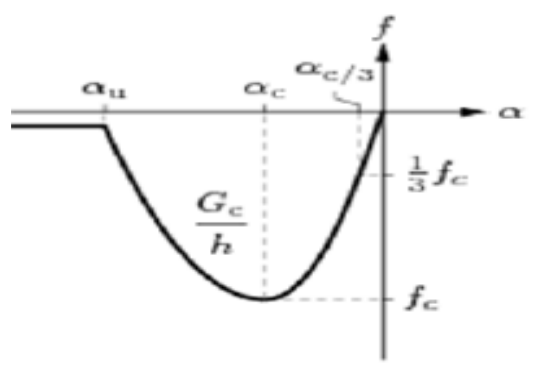

Şekil 6. Kil tuğlaların basınçta gerilme-şekil değiştirme ilişkilerini açıklayan parabolik ilişki

Çekme dayanımı, elastisite modülü, poisson oranı, söylenen sıra için $2 \mathrm{MPa}, 6000 \mathrm{MPa}, 0.14$ alınmıştır ve bu değerler önceki bir çalışmadan alınmıştır [18]. Aynı çalışmada belirtildiği üzere basınçtaki kırılma enerjisi 25.1 $\mathrm{N} / \mathrm{mm}$ alınmıştır. Tuğlanın basınç dayanımı $16 \mathrm{MPa}$ alınmıştır ve bu değer yerel üreticide Türk Standartlarına uygunluk amacıyla mevcut olan test sonuçlarından alınmıştır

\subsubsection{Harcın modellenmesi}

Harcı modellemek için Abaquste var olan CDP modeli kullanılmıştır. Dilatasyon açısı betondan farklı olarak 36.4 derece kabul edilmiştir. Harcın basınç dayanımı, young modülü, poisson oranı, çekme dayanımı, önceki bir çalışmada belirtildiği biçimde sırasıyla 6.2 MPa, $1750 \mathrm{MPa}$, 0.157, 0.61 MPa alınmıştır [18].

\subsubsection{Polimer malzemenin modellenmesi}

Kwiecien vd. [9-12] esnek polimer malzemenin nasıl modellenebileceğinden ve malzemenin mekanik özelliklerinden makalelerinde bahsetmiştir. Önceki çalışmaları incelenerek, polimer malzemenin elastisite modülü, poisson oranı, çekme dayanımı, söylenen sıra için 4 $\mathrm{MPa}, 0.49$, 1.4 MPa alınmıştır. Bu makaleler incelenerek, kauçuk malzeme modellemesinde kullanılan Mooney-Rivlin teorisinde gerekli olan parametreler belirlenmiştir. MooneyRivlin teorisi kauçuk malzeme modellemesinde kullanılan bir teoridir. [19, 23] Gams vd. nin [23] önceki deneylerinin sonuçlarına göre, Polimer Pm malzemesi için, $C_{01}$ katsayısı $0.53, C_{10}$ katsayısı 0.21 olarak hesaplanmıştır. Kauçuk benzeri malzemelerin modellenmesinde kullanılan Mooney -Rivlin Teorisi Denklem (4-8)'de gösterildiği üzere şöyledir:

$$
\mathrm{W}^{\mathrm{M}-\mathrm{R}}=\mathrm{C}_{10}\left(\Delta^{2}+\frac{2}{\Delta}-3\right)+\mathrm{C}_{01}\left(\frac{1}{\Delta^{2}}+2 \Delta-3\right)
$$

$$
\begin{gathered}
\mathrm{S}_{1}=\frac{\mathrm{F}}{\mathrm{A}_{0}}=\frac{\mathrm{dW}^{\mathrm{M}-\mathrm{R}}}{\mathrm{d} \Delta}=2\left(\mathrm{C}_{10}\left(\Delta-\frac{1}{\Delta^{2}}\right)+\mathrm{C}_{01}(1-\right. \\
\left.\left.\frac{1}{\Delta^{3}}\right)\right)=2\left(1-\frac{1}{\Delta^{3}}\right)\left(\Delta \mathrm{C}_{10}+\mathrm{C}_{01}\right) \\
\mathrm{E}_{0}=3 \mathrm{G}_{0}=6\left(\mathrm{C}_{10}+\mathrm{C}_{01}\right) \\
\mathrm{G}_{0}=2\left(\mathrm{C}_{10}+\mathrm{C}_{01}\right) \\
\Delta=\frac{\mathrm{L}}{\mathrm{L}_{0}}=\varepsilon+1
\end{gathered}
$$

$\mathrm{Bu}$ denklemlerde L, poliüretan bazlı kauçuk benzeri polimer pm malzemesinin yüklemeden sonraki uzunluğu, $\mathrm{L}_{0}$ yükleme öncesi ilk uzunluğu, $E_{0}$ elastisite modülü, $G_{0}$ kayma modülüdür.

\subsubsection{Mikro modelleme yaklaşımında harç ile malzeme arası etkileşimin modellenmesi}

Çerçeve ile duvar arası kısımdaki, harç ile tuğlalar arası etkileşimi tanımlamak için yüzey tabanlı kohesif davranış kullanılmıştır. Yüzey tabanlı kohesif davranış, kırma-ayırma modelini kullanarak, ihmal edilebilecek kadar küçük arayüzey kalınlıklı birleşimleri modellemek için basitleştirilmiş bir yöntem sağlamaktadır [20]. Yüzey tabanlı kohesif davranış formülleri kırma ayırma davranışı ile kullanılan kohesif elemanlar için kullanılan formüllerle çok benzerdir. [20] Şekil 7'de [20] görüldüğü üzere kırma ayırma kanunları birleşimin $\bmod 1, \bmod 2, \bmod 3$ göçme modlarındaki davranışlarını tanımlamak için kullanılmaktadır. Bir başka deyişle çekme ve kesme durumlarındaki göçme davranışlarını tanımlamak için kullanılmaktadır. İlk başta birleşim lineer davranmakta ve $\mathrm{K}_{\mathrm{n}}, \mathrm{K}_{\mathrm{s}}, \mathrm{K}_{\mathrm{t}}$ birleşimin rijitlikleri olmaktadır. Ancak ayrılmayı başlatan maksimum gerilme (Şekil 7'de $\mathrm{t}_{\mathrm{n}}^{\max }$ olarak görülüyor.) değerinden sonra birleşim arayüzeylerinin plastik davranışı başlamaktadır. $\mathrm{t}_{\mathrm{n}}^{\max }, \mathrm{t}_{\mathrm{s}}^{\max }, \mathrm{t}_{\mathrm{t}}^{\max }$ temas gerilmelerinin maksimum değerleri, $\delta_{\mathrm{n}}^{\max }, \delta_{\mathrm{s}}^{\max }, \delta_{\mathrm{t}}^{\max }$, temas ayrılmasının maksimum gerilmelere karşılık gelen değerleri, $\delta_{\mathrm{n}}^{\mathrm{f}}, \delta_{\mathrm{s}}^{\mathrm{f}}, \delta_{\mathrm{t}}^{\mathrm{f}}$ göçmedeki ayrılma değerleridir.

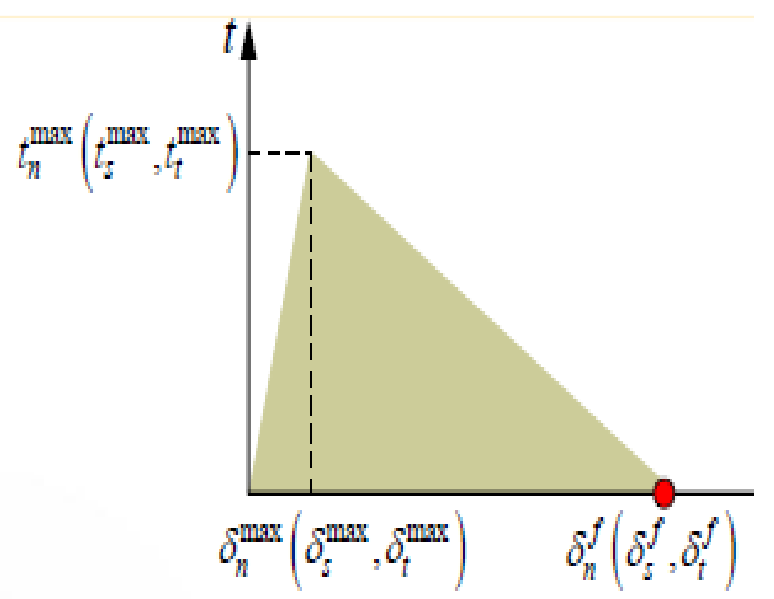

Şekil 7. Birleşimlerin kırılma -ayrılma davranışı 
Hasar başlangıcını (plastik davranışa geçişi) tanımlamak için maksimum gerilme kriteri kullanılmıştır. Birleşimin çekme dayanımı $0.56 \mathrm{MPa}$, kritik kesme gerilmesi değeri de Mohr-Coulomb sürtünme formülü ile hesaplanarak $10 \mathrm{MPa}$ alınmıştır. Mohr-Coulomb davranışında, kohezyon katsayısı sıfır alınmış ve sürtünme katsayısı 0.7 kabul edilerek basınçla çarpılmış ve kritik kesme değeri elde edilmiştir. Bunlara ek olarak birleşimin göçmesi tamamlandıktan sonraki kayma davranışını modellemek için, sürtünme katsayısı 0.7 olan bir Mohr-Coulomb kayma davranışı tanımlanmıştır. Bu şu manaya gelir ki birleşim kritik gerilme değeri aşıldıktan sonra kayacaktır. Birleşimin kırılma enerjileri daha önce yapılan bir çalışmadaki yığma birleşimlerin, kohesif elemanlar kullanılarak tanımlandığg bir çalışmadan alınmıştır [18] Abaqus manuelde, [20] söylendiği gibi yüzey tabanlı kohesif davranış formülasyonu kırılma ayırma davranışları ile kullanılan kohesif elemanlar için kullanılan formülasyonla çok benzerdir. $\mathrm{Bu}$ yüzden varsayılmıştır ki aynı kırılma enerjileri (kırılma-ayrılma grafiğinin altındaki alan) yüzey tabanlı kohesif davranışı tanımlamak için de kullanılabilir. 1. Mod için kırılma enerjisi $0.017 \mathrm{~N} / \mathrm{mm}$, 2. Mod için kırılma enerjisi $0.085 \mathrm{~N} / \mathrm{mm}$ alınmıştır ve karışık mod davranışı Abaqus'te benzeggaghKenane kuralı uygulanarak dikkate alınmıştır. Önceki bir çalışmada da belirtildiği üzere eğer kritik karışık mod kırılma enerjisi Benzeggagh-Kenane kuralı kullanılarak tanımlanırsa bu ikinci-üçüncü mod kırılma enerjileri aynı olan durumlarda yerinde olur [21]. Ve aynı çalışmada Benzeggagh-Kenaneh kuralındaki üs ( $\eta$ ), gevrek davranışta 2 olarak tavsiye edilmiştir. Benzeggah-Kenaneh kural Denklem (9)'da gösterilmektedir. Burada $G_{\mathrm{TC}}$ kritik karışık mod kırılma enerjisi, $G_{I I}$ ve $G_{I I I}$ kesme modu kırılma enerjileri, $G_{I C}$ ve $G_{\text {IIC }}$ ilgili modlardaki kritik kırılma enerjileridir.

$$
G_{T C}=G_{I C}+\left(G_{I I C}-G_{I C}\right)\left(\frac{G_{I I}+G_{I I I}}{\left.G_{I}+G_{I I}+G_{I I I}\right)}\right)^{\eta}
$$

Viskovic vd. [22] tarafından yapılan önceki bir çalışmada esnek birleşimlerin kırılma enerjileri harçlı birleşimlerle kıyaslanmıştır ve görülmüştür ki polimer malzemeli esnek birleşimler çok daha fazla hasar enerjisi ve toplam kırılma enerjisine sahiptirler. Onların çalışmalarında gösterilmiştir ki, esnek birleşimi göçertmek için gerekli enerji çekme modunda harçlı birleşime nazaran 16 kat ve kesme modunda 14 kat daha fazladır. Bu yüzden bu çalışmada polimerli birleşimlerin kırılma enerjileri 1 . Mod için $0.272 \mathrm{~N} / \mathrm{mm}$ ve 2. Mod için $1.19 \mathrm{~N} / \mathrm{mm}$ alınmıştır.

\subsubsection{Modelin analizi}

Şekil 8'de görüldüğü üzere, 3 boyutlu C3D8R elemanı donatı haricindeki tüm malzemeler için kullanılmıştır. C3D8R elemanı 8 noktalı lineer bir eleman olup, azaltılmış integrasyonlu ve kumsaati kontrollüdür.

Çerçevenin yüklemesi için explicit(açık) dinamik analiz yapılmıştır. Çünkü explicit (açık) dinamik analiz Abaqus’te nonlineer quasi-statik problemler ve hızlı ve temas içeren problemler için çok uygundur. Hareket denklemini çözmek için Newton-Raphson iterasyonunu kullanmaz, onun yerine merkezi farklar iterasyon metodunu kullanır.

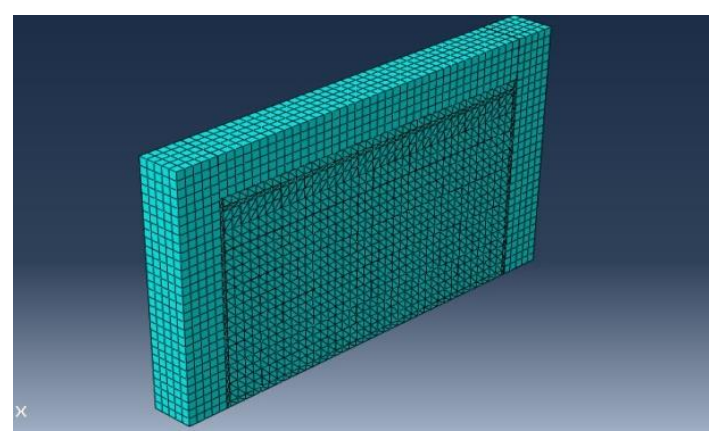

Şekil 8. Birleşimlerin kırılma -ayrılma davranışı

Merkezi farklar iterasyonunda rijtlik, kütle ve sönüm matrisleri her adımda tekrar oluşturulmaz ve I+1'inci adımdaki deplasmanlar I ve I-1'inci adımdaki deplasmanlar kullanılarak bulunur. Bu sebeple bilgisayar analiz maliyeti düşüktür. Büyük bir bilgisayar gücü gerekmez ve bilgisayar gücü genellikle eleman iç kuvvetlerinin bulunmasında kullanılır. [14]

Quasi-statik gibi bir yükleme açık(explicit) analiz kullanılarak simule edilecekse, başarılı bir analiz için bazı şartlar dikkate alınmalıdır. Çünkü bu durumda statik bir yükleme dinamik bir yüklemeye çevrilmiştir. Eğer eylemsizlik kuvvetleri bir seviyenin altında tutulursa, problemin statik bir problem gibi olduğu kabul edilebilir. Bunu anlamak için kinetik enerji/toplam iç enerji oranı analizden sonra kontrol edilir ve bu oran eğer 0.10 değeri ve altındaysa, yükleme statik bir yükleme gibi kabul edilebilir. [14].

Açık(explicit) analizin diğer bir hususu da mantıklı bir yükleme zamanının ayarlanmasıdır. Eğer statik yüklemedeki doğal zaman dikkate alınırsa, bu dinamik bir olaya nazaran çok yavaş olduğu için, bu kadar uzun süre analiz yaptırılması bilgisayar kullanımı açısından ekonomik olmaz. Daha önce belirtildiği üzere olayın ivmelendirilmesi durumunda da, kinetik enerji/toplam iç enerji oran şartı sağlanmayabilir. Bunu aşmak için Abaqus’teki kütle oranlama özelliği kullanılabilir. Bu özellik Denklem (10) ve (11)'de şöyle ifade edilebilir [14].

$$
\begin{gathered}
\Delta_{t}=\frac{L_{e}}{C_{d}} \\
C_{d}=\sqrt{E / \rho}
\end{gathered}
$$

Formüllerdeki $\mathrm{L}^{\mathrm{e}}$ karakteristik eleman uzunluğu, $\mathrm{c}_{\mathrm{d}}$ ise lineer elastik malzemenin dilatasyonal dalga hızıdır. Formüllerden görüldüğü üzere yoğunluğu arttırırsak, analiz süresini kısaltabiliriz. Çünkü nümerik analizdeki stabil zaman arttırımı bununla ilişkilidir. $\mathrm{Bu}$ çalışmada kütle oranlama oranı 2 olarak kullanılmıştır.

Analizde 2 sn içinde 20mm'ye (\%2.5 öteleme oranı) ulaşan yanal bir itme çerçeveye yüklenmiştir. Tablo 1 'de 
görülmektedir. $\mathrm{Bu}$ çalışmada yüklemenin $\% 2.5$ yükleme oranıyla sınırlandırılma sebebi, kolonların bu değerden sonraki yüklemelerde ileri hasar bölgesi olarak tanımlanan performans bölgesine (\%3) çok yaklaşmasıdır ve pratikte bu değerden sonrasının anlamlı olmayacağı düşüncesidir. $\mathrm{Bu}$ çalışmada dizayn edilen çerçeve 2018 yönetmeliğinden önce tasarlanmış ve ileride planlanan deney için inşa ettirilmiş ve o günkü mevcut yönetmelik olan TDY 2007'de yeni bina tasarımı için etkin göreli kat ötelemeleri değeri \%2 ile sınırlanmıştı. Ayrıca kolonlara $A_{c}$ kolon kesit alanı, $f_{c k}$ C25 karakteristik basınç dayanımı olmak üzere; $0.3 \times \mathrm{A}_{\mathrm{c}} \mathrm{xf}_{\mathrm{ck}}$ olan eksenel yük uygulanmıştır.

Tablo 1. Çerçeveye yükleme zamanı içinde verilen yükleme

\begin{tabular}{cc}
\hline Zaman(s) & Deplasman $(\mathrm{mm})$ \\
\hline 0 & 0. \\
0.25 & 2.5 \\
0.5 & 5 \\
0.75 & 7.5 \\
1 & 10 \\
1.25 & 12.5 \\
1.5 & 15 \\
1.75 & 17.5 \\
2 & 20 \\
\hline
\end{tabular}

\section{Bulgular ve tartışma}

\subsection{Duvarsız çerçeve sonuçları}

Abaqus'ün görüntüleme modülünde yük-deplasman grafikleri görülebilmektedir ve buradan data alınıp excel programına aktarılabilmektedir. Analizden sonra Yükdeplasman, enerji, ve gerilme değerleri elde edilmiştir. Boş çerçeve Şekil 9'da görüldüğü gibi 50KN taşımıştır. Eğer 0.75 x maksimum yük'e karşılık gelen sekant rijitliği, başlangıç rijitliği olarak kabul edilirse, başlangıç rijitliği: $16237.87 \mathrm{~N} / \mathrm{mm}$ 'dir. Grafik incelenirse, akma yer değiştirmesinin $2.5 \mathrm{~mm}$ olduğu söylenebilir.

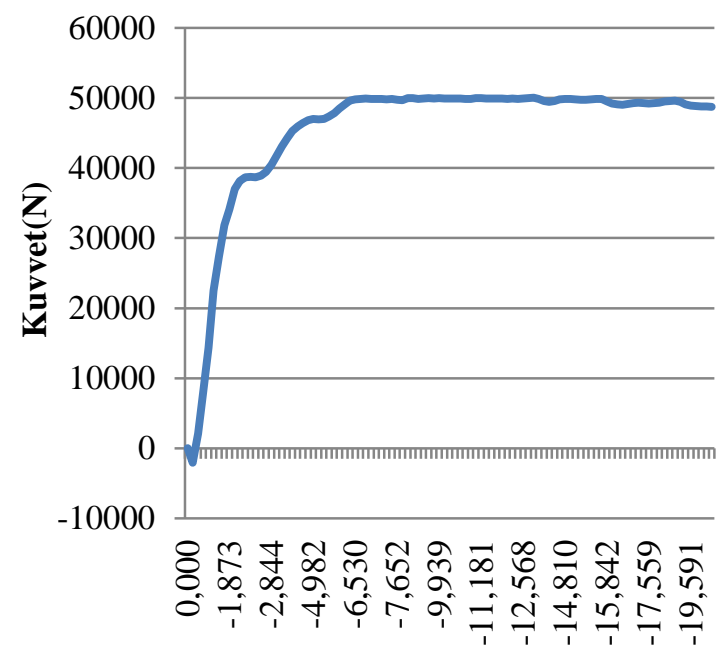

\section{Deplasman ( $\mathbf{m m})$}

Şekil 9. Duvarsız çerçeveye ait yük(newton) -deplasman (mm) grafiği
Eğer Kinetik enerji/iç enerji grafikleri incelenirse, bu oranın düşük olduğu ve yüklemenin açık( explicit) dinamik analiz olmasına rağmen statik itme yüklemesi gibi düşünülebileceği görülür. Şekil $10^{\prime}$ da enerji grafikleri gösterilmiştir.

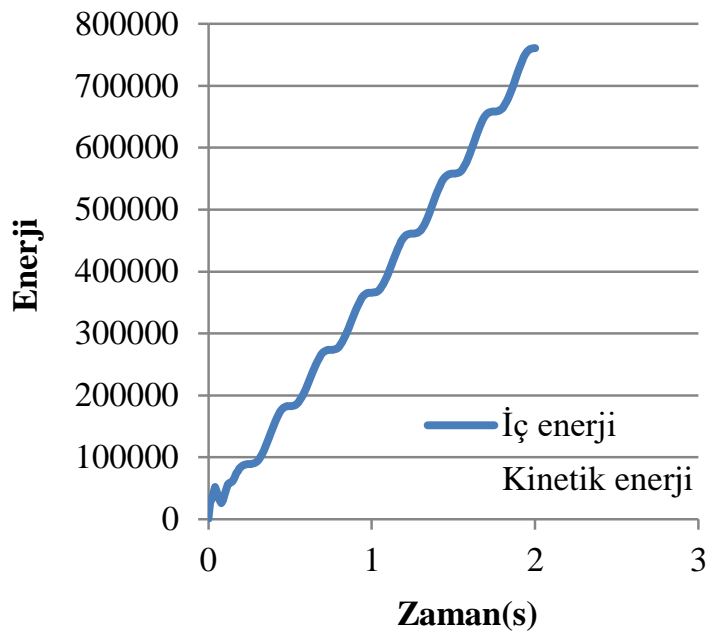

Şekil 10. Duvarsız çerçeve yüklemesinin iç enerji (mavi) ve kinetik enerji(kırmızı) grafikleri

Gerilme durumu da yüklemenin son saniyesindeki S22 (yerçekimi doğrultusu) gerilmesi olarak Şekil 11'de görülmektedir.

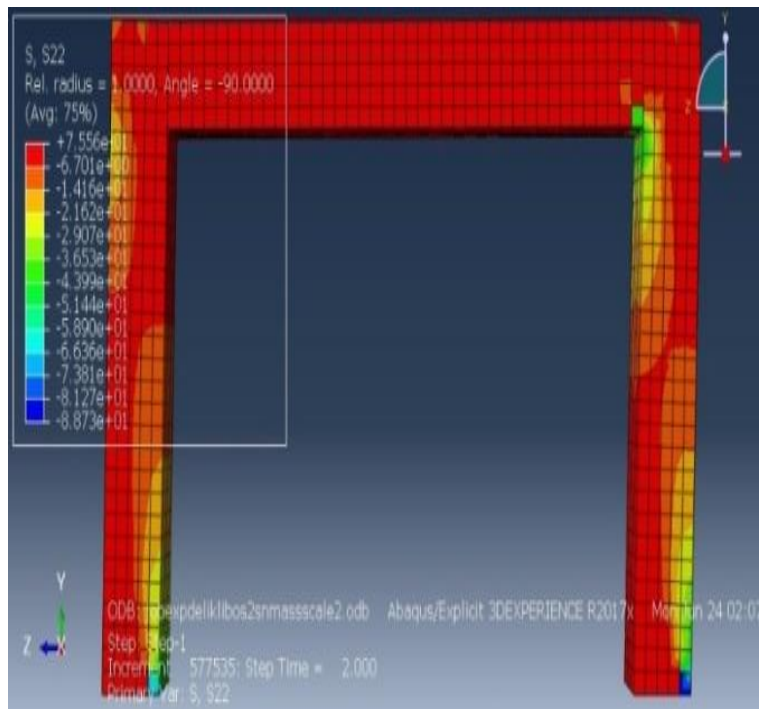

Şekil 11. Duvarsız çerçevenin yüklemenin 2 . saniyesindeki gerilme durumu

\section{2 Çerçeve duvar arası harç olan çerçeve}

Yük deplasman ilişkileri, enerji grafikleri, gerilme değerleri analizlerden sonra görülmüştür. Dolgu duvarlı ve çerçeve duvar arası harçlı birleşimli çerçeve Şekil 12'de görüldüğü üzere $70 \mathrm{KN}$ yük taşımıştır. Eğer maksimum yükün 0.75 'inin sekant rijitliği, başlangıç rijitliği olarak kabul edilirse, başlangıç rijitliği $34163.66 \mathrm{~N} / \mathrm{mm}$ 'dir ki bu dolgu duvarsız çerçevenin 2.10 katıdır. Harçsız bloklar 
geleneksel dolgu duvarlar kadar çerçeve rijitliğini arttırmamaktadır. Grafikten, akma yer değiștirmesinin $2.5 \mathrm{~mm}$ olduğu kabul edilebilir. Bu, harçsız bloklu dolgu duvarın akma yer değiștirmesine ve akma sünekliğine negatif bir etkisi olmadığı anlamına gelir. Bu sonuç önceki çalışmalar [4] dikkate alınırsa uygun bir sonuçtur. Bu yüzden, bu çalışmanın yazarlarına göre, harçsız bloklu dolgu duvarın tasarımı zayıf bir basınç çubuğu ve daha fazla bir viskoz sönümün birleşimi olarak düşünülebilir. Başlangıç rijitliği kullanılarak, bu başlangıç rijitliği duvar yerine basınç çubuğu içeren çerçevenin başlangıç rijitliğine eşitlenerek, basınç çubuklu eşdeğer bir çerçeve yapı dizaynı için düşünülebilir. Ayrıca geleneksel dolu bloklu yığma duvarın betonarme bir çerçevenin başlangıç rijitliğini 30 kat arttırabildiğinden önceki çalışmalarda [3] bahsedildiği göz önüne alınırsa, harçsız duvarın rijitliği neredeyse arttırmadığı düşünülebilir ve bu da depremlerde katlar arası rijitlik farkları nedeni ile oluşan düzensizliklerin meydana getirebileceği sorunların bertaraf edilmesi anlamına gelir.

Bir diğer husus ta rijitliğin artmamasının yapı periyodunu geleneksel duvarlı yapıdan daha uzun hale getirmesi ve uzun periyot ile yapıya gelen deprem kuvvetlerinin azalabileceği gerçeğidir. Bunlara ek olarak unutulmamalıdır ki önceki çalışmalarda görüldüğü üzere [7] , kolonlar kesmeden kırıldığında sürtünmeden dolayı oluşan enerji tüketimi artacak ve duvar çerçevenin düşey yüklerini taşıyacaktır. Enerji grafiklerine bakıldığında, kinetik enerji/toplam iç enerji oranının düşük olduğu Şekil 13 'te görülmektedir. Ve dolgulu çerçevenin sürtünme nedeniyle olan enerji tüketimi Şekil 14 'te görülmektedir. Bu enerji daha önce bahsedildiği şekilde [4] Jacobsen yaklaşımı kullanılarak eşdeğer bir sönüm oranı hesaplamakta kullanılabilir. (N-mm cinsinden Abaquste hesaplanmıştır.)

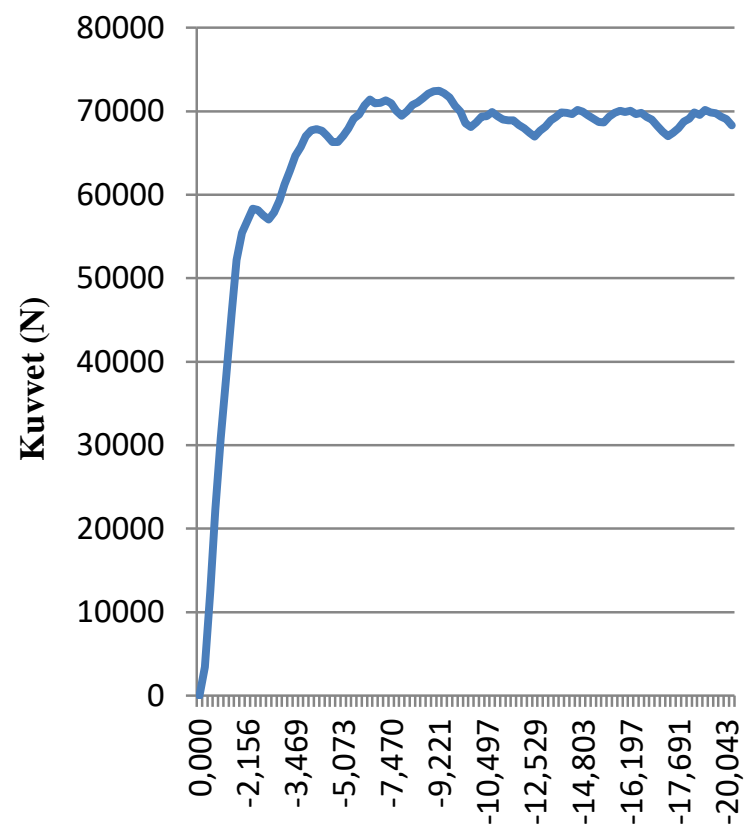

Deplasman (mm)

Şekil 12. Harçsız bloklu ve harçlı birleşimli çerçevenin yük deplasman grafiği

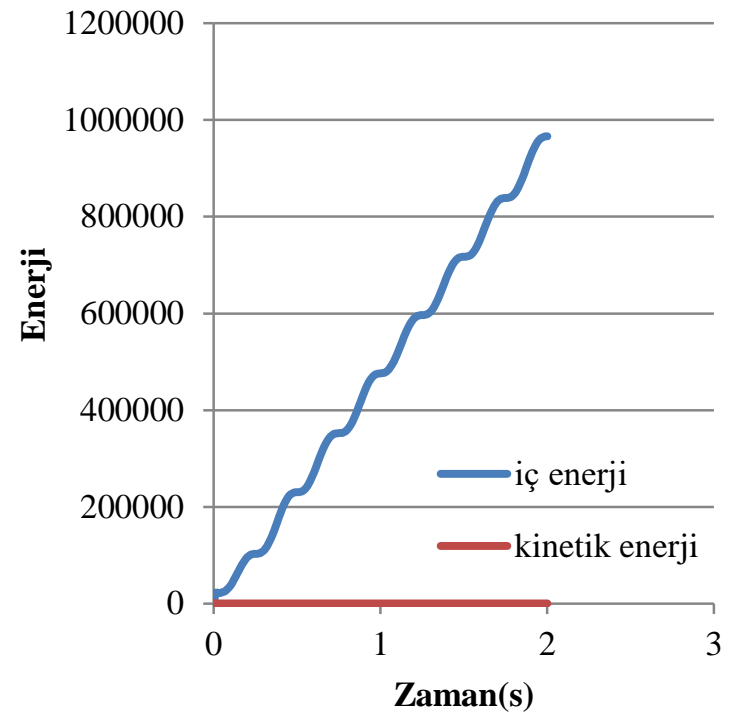

Şekil 13. Harçsız duvarlı ve duvar çerçeve etkileşimi harçlı olan çerçevenin iç enerji(mavi) ve kinetik enerjisi

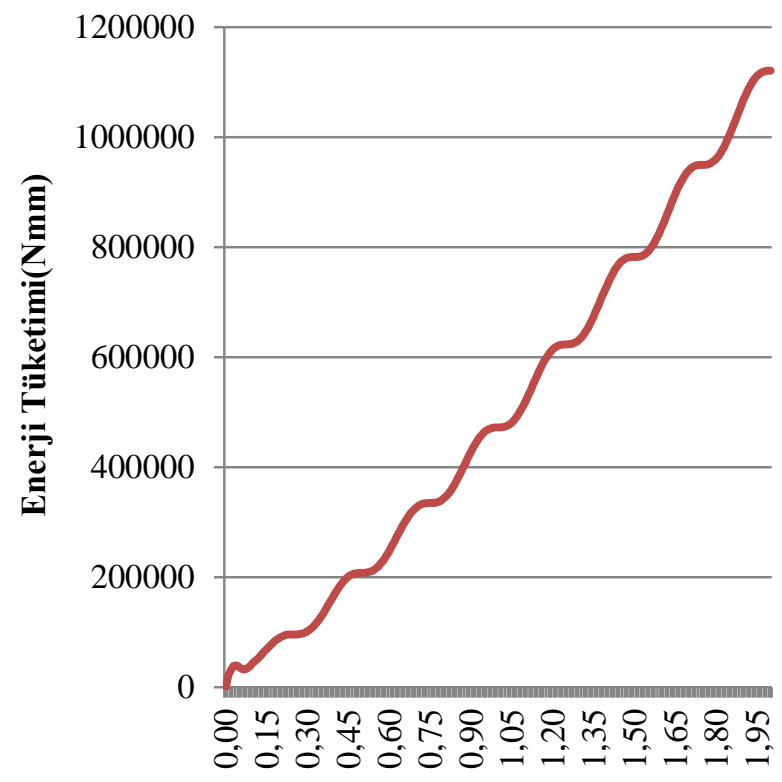

Deplasman (cm)

Şekil 14. Harçlı birleşimli sistemin yükleme zamanına göre toplam enerji tüketimi (N-mm vs deplasman)

Yükleme sonundaki S22 gerilmesini gösteren (yerçekimi yönü) gerilme grafiği Şekil 15' te görülmektedir.

\section{3 Çerçeve duvar arası polimer yapıştırııılı çerçeve}

Çerçevenin yük deplasman ilişkileri, enerji grafikleri, gerilme değerleri analizden sonra elde edilmiştir. Şekil 16'da görüldüğü üzere, harçsız bloklu ve polimer birleşimli çerçeve $80 \mathrm{KN}$ maksimum yük taşımıştır ki bu harçlı birleşimli, harçsız bloklu çerçeveden $\% 14$ daha fazladır. 


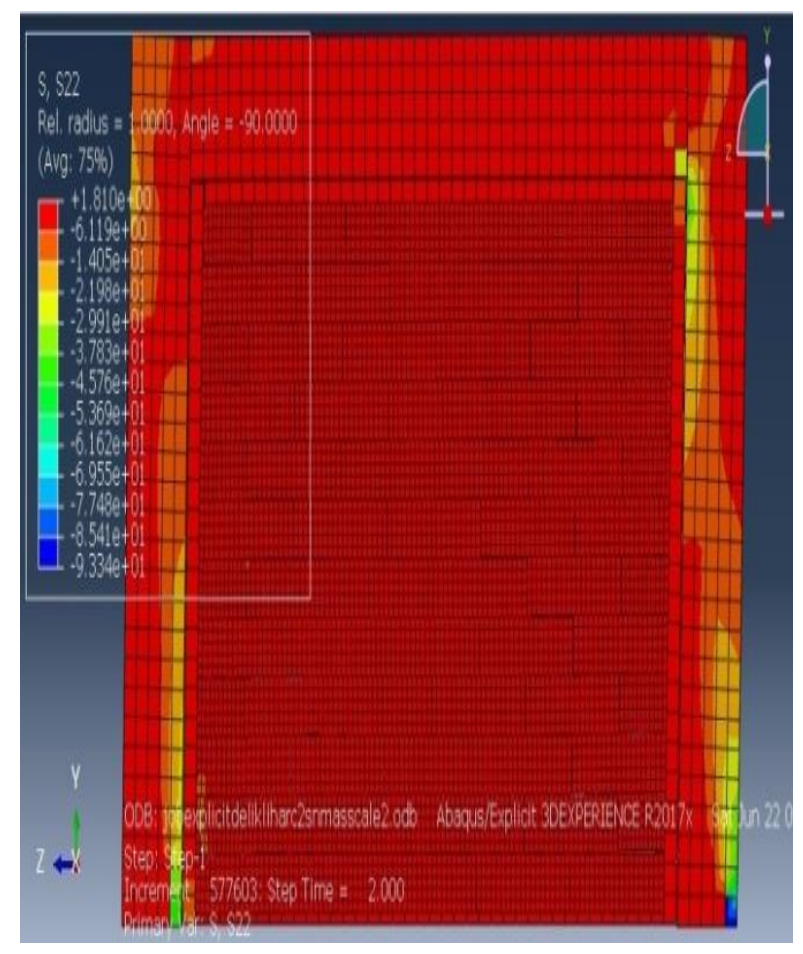

Şekil 15. Harçsız bloklu harçlı birleşimli çerçevenin yüklemenin 2. saniyesindeki gerilme durumu

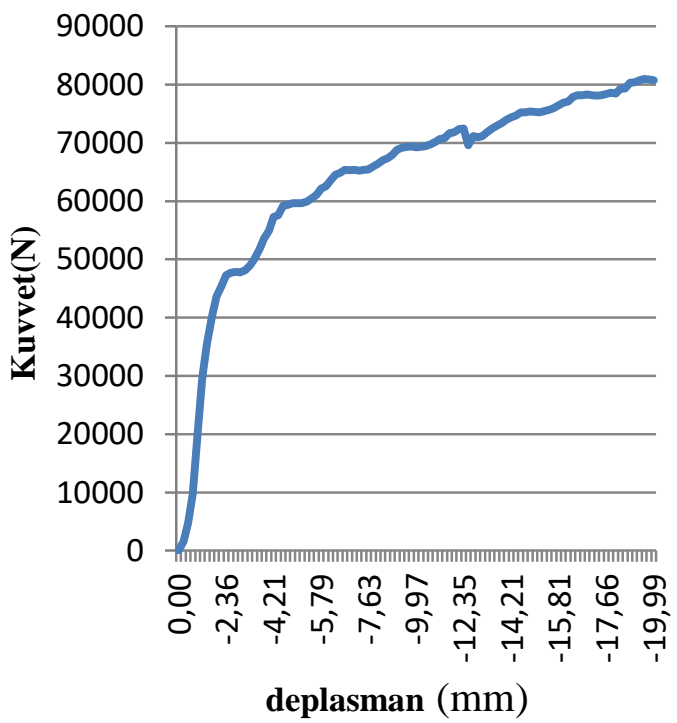

Şekil 16. Polimer yapıştırıcılı harçsız bloklu çerçevenin yük deplasman grafiği

Eğer başlangıç rijitliği, maksimum yükün 0.75 'inin sekant rijitliği olarak kabul edilirse, başlangıç rijitliği: $11817.11 \mathrm{~N} / \mathrm{mm}$ olmaktadır ki dolgu duvarsız çerçeveden düşüktür. Akma yer değiştirmesini grafikten $2.5 \mathrm{~mm}$ olarak kabul edebiliriz. Harçsız bloklu dolgu duvar yapının akma yer değiştirmesine ve sünekliğine negatif bir etki yapmamaktadır. Ve polimerli durumda, dolgu duvarsız ve harçlı birleşimli durumlarda görmediğimiz şekilde yük akmadan sonra artış göstermektedir. Bu sonuç düzensizlikler ve yapı periyodu ile ilgili harçlı birleşimli, harçsız duvar sisteminde belirtilen avantajlardan bile daha iyidir.

Enerji grafikleri incelendiğinde yine görülmüştür ki, kinetik enerji/toplam iç enerji oranı Şekil 17'de gösterildiği üzere düşüktür. Çerçevenin Sürtünme dolayısıyla kaybettiği enerji Şekil 18'de görülmektedir. Bu enerji daha önce bahsedildiği şekilde Jacobsen metodu kullanılarak eşdeğer bir sönüm oranı hesaplamak için kullanılabilir.

Yükleme sonundaki S22 gerilmesini gösteren (yerçekimi yönü) gerilme grafiği Şekil 19'da görülmektedir. Şekil 18 'deki enerji tüketimi incelendiğinde, harçlı birleşime nazaran sürtünme enerjisinin azaldığ 1 görülmektedir. $\mathrm{Bu}$ harç yerine kullanılan kauçuk benzeri polymer pm malzemesinin deformasyon yeteneği ile gerilme yığılmalarını azaltması sayesinde olmuştur.

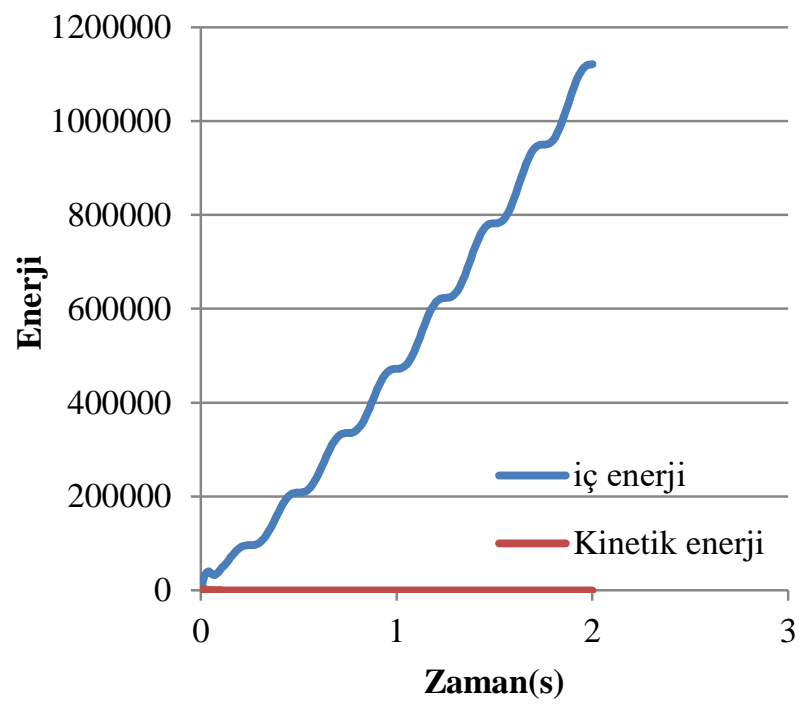

Şekil 17. Harçsız bloklu ve polimer birleşimli çerçevenin iç enerji(mavi) ve kinetik enerji (kırmızı) grafikleri

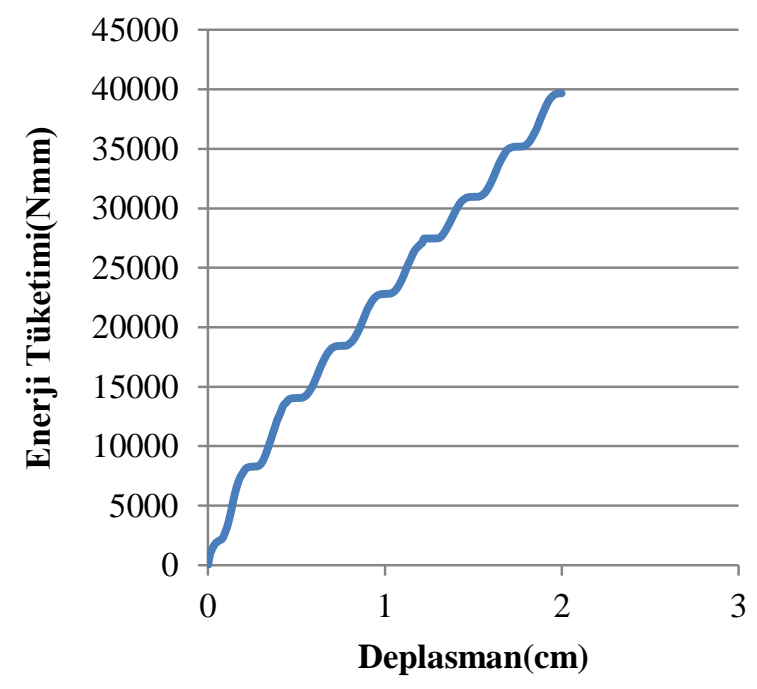

Şekil 18. Harçsız bloklu ve polimer birleşimli çerçevenin tükettiği sürtünme enerjisi (N-mm vs deplasman $(\mathrm{cm})$ 


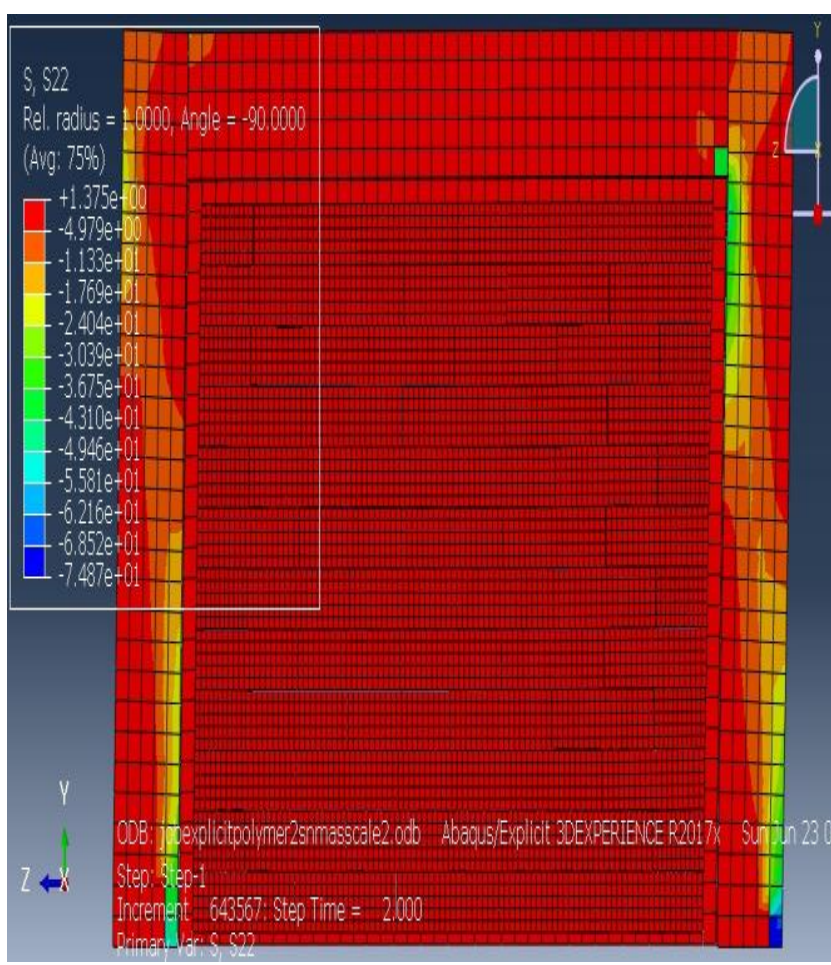

Şekil 19. Harçsız duvarlı polimer birleşimli çerçevenin yüklemenin 2. saniyesine ait gerilme durumu

\section{Sonuçlar}

Çalışma kapsamında harçsız duvarlı-duvarsız ve farklı dolgulu 3 farklı betonarme çerçeve, düşey yükler altında $20 \mathrm{~mm}$ yanal itmeye tabi tutularak nümerik analiz ile incelenmiştir. Sonuç olarak, görülmüştür ki harçsız duvar, sistemin enerji tüketim kapasitesini arttırmaktadır ve harçsız bloklu duvar ile çerçeve arasında var olan bağlayıcının cinsi bunlardan müteşekkil yapı davranışını değiştirmektedir. Şekil 20'de daha önce verilen yük-deplasman grafiklerinin karşılaştırmalı görünümü görülmektedir.

Harçsız bloklu ve harçlı birleşimli çerçevenin başlangıç rijitliği dolgu duvarsız çerçevenin 2.10 katıdır. Harçsız bloklu dolgu duvar geleneksel duvar kadar çerçeve rijitliğini arttırmamakta ve akma yer değiştirmesine ve sünekliğine negatif bir etki yapmamaktadır. Bu yüzden bu çalışmanın yazarlarına göre, harçsız bloklu dolgu duvar zayıf bir basınç çubuğu ve daha yüksek bir viskoz sönümün birleşimi şeklinde modellenebilir. Başlangıç rijitliği kullanılarak basınç çubuklu eşdeğer bir çerçeve yapı tasarımı için düşünülebilir.

Harçsız duvarlı sistem rijitliği çok fazla arttırmadığından, yapılarda katlar arası rijitlik farklarından dolayı oluşabilecek düzensizlikleri gidermede faydalı olacaktır.

Harçsız duvarlı çerçeve, duvarsız çerçeveye nazaran $\% 2.5$ öteleme oranı için, $\% 40$ daha fazla yatay yük taşımıștır. Duvar ile çerçeve arasında bağlayıcı olarak Polimer Pm kullanıldığı durumda ise $\% 60$ daha fazla yatay yük taşımıştır. $\mathrm{Bu}$ olgu betonarme çerçevedeki gerilme yığılmalarının Polimerli durumda azalmasıyla açıklanabilir.

Polimer birleşimli ve harçsız duvarlı çerçeve bütün bu sebeplerden sismik tasarım ve sismik güçlendirme için iyi bir alternatiftir.

Harçsız duvarların önceki çalışmalarda, kolonlar kesmeden kırıldığında, sürtünmeyle daha fazla enerji tükettiği ve düşey yükleri taşıdığı saptanmıştı. Bu olgu da bu çalışma sonuçlarıyla birlikte değerlendirilirse, polimer pm kullanımı ile gerilme yığılmaları azaltılarak, ek bir dayanım sağlanabilir.

Daha fazla araştırma için deneysel çalışma gerekmektedir.

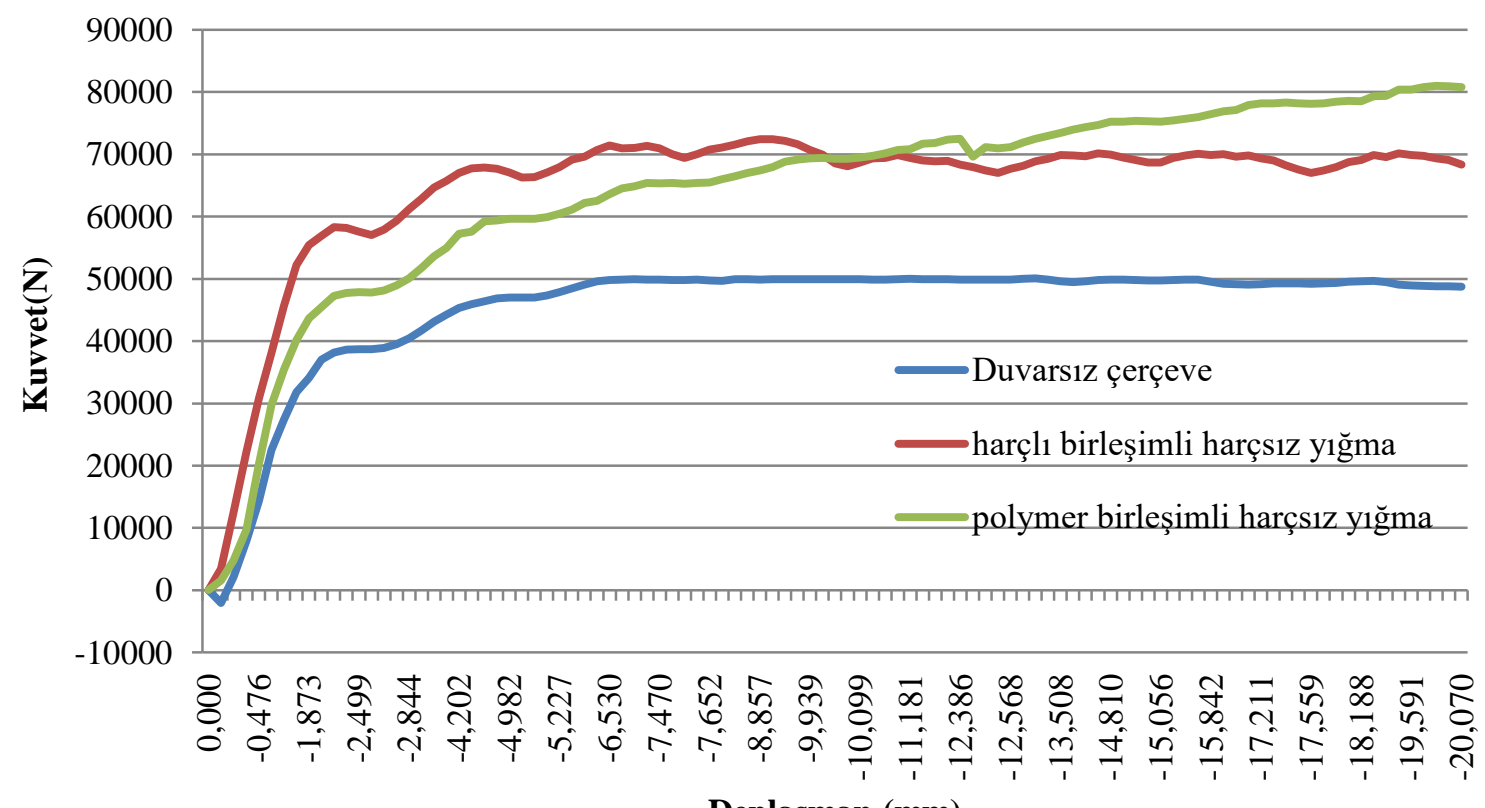

\section{Deplasman (mm)}

Şekil 20. Çerçevelere ait yük deplasman eğrilerinin karşılaştırmalı görünümü 


\section{Çıkar çatışması}

Yazarlar çıkar çatışması olmadığını beyan etmektedir.

\section{Benzerlik oranı (iThenticate): \%11}

\section{Kaynaklar}

[1] S. Yıldırım, G. Aşık, B, Erkus, Y. Yetimoğlu, Y. Tonguç, and I. Mualla, Retrofit of a reinforced concrete building with friction dampers, Second European Conference on earthquake engineering and seismology, İstanbul, Türkiye, 25-29 Ağustos 2014.

[2] G. Amato, M. Fosetti, L. Cavaleri, An updated model of equivalent diagonal strut for infill panels. Eurocode 8 perspectives from the Italian Standpoint Workshop, 119-128, Napoli, Italya, 2009.

[3] K. Lin, Y. Z. Totoev, H. Liu, T. Guo, In plane behaviour of a reinforcement concrete frame with a dry stack masonry panel. Mdpi materials, 9, 108, 2016. https://doi.org/10.3390/ma9020108

[4] Y. Totoev, Design procedure for semi interlocking masonry. Journal of civil engineering and architecture, 9, 517-525, 2015. https://doi.org/10.17265/19347359/ 2015.05.003

[5] A. Hossain, and Y. Totoev, Energy dissipation of framed semi interlocking masonry panel under large displacement. 10th Australian Masonry Conference, Sydney, Australia,11-14 February 2018.

[6] Y. Totoev and A. Al. Harty, Semi interlocking masonry as infill wall system for earthquake resistant buildings. The Journal of Engineering Research, 13(1), 33-41, 2016. http://doi.org/10.24200/tjer.vol13iss1pp33-41

[7] Y. Sanada, N. Yamauchi, E, Takahashi, Y. Nakano, and Y. Nakamura, Interlocking block infill capable of resisting out-of-plane loads. The 14th World Conference on Earthquake Engineering, Beijing, China, 12-17 October 2008.

[8] S. Misır, Ö. Özcelik, S. Girgin, S. Kahraman, Experimental work on seismic behaviour various types of masonry infilled RC frames. Structural Engineering and Mechanics, 44(6), 763-774, 2012. http://doi.org/ 10.12989/sem.2012.44.6.763

[9] A. Kwiecien, Highly deformable polymers for repair and strengthening of cracked masonry structures. International Journal of Engineering Technology, 2(1),182-196,2013. http://doi.org/10.5176/2251-3701_ 2.1.53

[10] A. Kwiecien, G. Felice, D. V .Oliveira, B. Zajac, A. Bellini, S. De Santis, B. Ghiassi, G. P. Lignola, P. B. Lourenço, C. Mazzotti, A. Prota, 2015, Repair of composite to masonry bond using flexible matrix. Materials and Structures, 49, 2563-2580, 2015, https://doi.org/10.1617/s11527-015-0668-5
[11] A. Kwiecien, Shear bond of composites to brick applied highy deformable, in relation to resin epoxy interface materials. Materials and Structures, 47, 2005-2020, 2014. https://doi.org/10.1617/s11527-014-0363-y

[12] A. Kwiecien, M. Gams, and B, Zajac, Numerical modelling of flexible polymers as the adhesive for frps, The 12th International Symposium on Fiber Reinforced Polymers as The Adhesive for FRPs. Nanjing, China, 14-16 October 2015

[13] I. Al-Shaikh, and N. Falah, Numerical analysis of masonry infilled RC frames. Journal of Science and Technology, 19(2), 2014.

[14] C. Demir, Seismic behaviour of historical stone masonry, PHD Thesis, Istanbul Technical University, İstanbul, Turkey, 2012.

[15] F. Birdal, Analytical modelling and experimental investigation of RC structures. PHD thesis, Kayseri University, Kayseri, Turkey, 2015.

[16] Y. T. Obaidat, Structural retrofitting of concrete beams using FRP. PHD thesis, Lund University, Lund, Sweden, 2011.

[17] S. Ergun, Betonarme kirișlerin kesme kapasitesinin dıș donatılar ile arttırılması, Doktora Tezi, Manisa Celal Bayar Üniversitesi, Manisa, Türkiye, 2014.

[18] J. R. Van Noort, Computational modelling of masonry structures, Master thesis, Delft University of Technology, Delft, Netherlands, 2012.

[19] S. Erkek, Kauçuk kap1 stoperinin hiperelastik ve viskoelastik modellenmesi ve sonlu elemanlar yöntemi ile analizi, Y. Lisans Tezi, Uludağ Üniversitesi, Bursa, Türkiye, 2016.

[20] Dassault Systems Simula Abaqus, Modelling fracture and Failure, Lecture 6

[21] K. F. Abdulah, L. S. Cunningham, M. Gillie Simulating masonry behaviour using a simplified micro model approach, Engineering Structures, 151,349-365, 2017. http://doi.org/10.1016/j.engstruct.2017.08.021

[22] A. Viskovic, L. Zuccarino, A. Kwiecien, B, Zajac, M. Gams, Quick seismic protection of weak masonry infilling in filled frame structures using flexible joints, Key Engineering Materials, 747, 628-637, 2017. https://doi.org/10.4028/www.scientific.net/KEM.747. 628

[23] M. Gams, A. Kwiecien, J. Korelc, T. Rousakis, A. Viskovic, Modelling of deformable polymer to be used for joints between infill masonry walls and R.C. frames. Procedia Engineering, 193, 455-461, 2017. https://doi.org/ 10.1016/j.proeng.2017.06.237. 